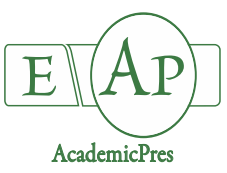

Ahmadpour R and Armand N (2020)

Notulae Botanicae Horti Agrobotanici Cluj-Napoca 48(3):1248-1259

DOI: $10.15835 /$ nbha48311834

Research Article

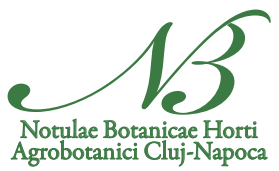

\title{
Effect of ecophysiological characteristics of tomato (Lycopersicon esculentum L.) in response to organic fertilizers (compost and vermicompost)
}

\author{
Raheleh AHMADPOUR, Nezam ARMAND* \\ Department of Biology, Faculty of Science, Behbahan Khatam Alanbia University of Technology, Khuzestan, Iran; \\ Ahmadpour@bkatu.ac.ir;Armandnezam@yahoo.com (*correspondingauthor)
}

\begin{abstract}
The organic fertilizers such as urban wet-waste compost and vermicompost can improve the physicochemical properties of soil and have a favourite effect on plants growth due to the high nutrient content, high water holding capacity, plant growth regulators, and beneficial microorganisms. In this regard, this study was conducted to evaluate the organic fertilizer mixture on the physiological and morphological indices of tomato seedlings under greenhouse conditions. The experiment was done as factorial in a completely randomized design with 3 replications. The evaluated factors included the vermicompost fertilizer $(0,10,20$, $30 \mathrm{wt} \%)$, and the urban wet-waste compost $(0,10,20,30 \mathrm{wt} \%)$. In evaluation of the simple-effects of vermicompost and urban wet-waste compost the results showed that the $30 \mathrm{wt} \%$ level compared to the control sample increased the leaf area $(+12.28 \%$ and $+9.33 \%)$. It also increased the number of leaves $(+17.5 \%$ and $+22.9 \%)$, dry weight of root $(+17.3 \%$ and $+16.9 \%)$, chlorophyll-b content $(+4.9 \%$ and $+12.3 \%)$, carotenoids $(+2.9 \%$ and $+7.9 \%)$, and the total chlorophyll content $(+23.7 \%$ and $+13.8 \%)$. Results of evaluating the treatments showed that the vermicompost and urban wet-waste compost mixture in $30 \mathrm{wt} \%$ level $\left(\mathrm{V}_{4} \mathrm{C}_{4}\right)$ caused significant increase in the plant height, leaf dry weight, root length, relative water content, cell membrane stability coefficient, efficiency of photochemical performance of PSII and the chlorophyll-a content (compared to other treatments especially low levels of organic fertilizer consumption). According to the final results of this study, using the vermicompost and urban wet waste compost mixture in $30 \mathrm{wt} \%$ level is recommended to improve the morphological and physiological traits of tomato in greenhouse conditions.
\end{abstract}

Keywords: compost; membrane stability coefficient; morphological traits; relative water content; vermicompost

\section{Introduction}

Tomato (Lycopersicon esculentum Mill. syn. Solanum lycopersicum L.) is one of most important cultivated plant in the world, and is one of most important greenhouse vegetables (Ejaz et al., 2011). It is too an important source of antioxidants (such as Carotenoids and Lycopene), polyphenols and organic acids (Giovanelli and Paradiso, 2002). Meanwhile the regular consumption of tomato leads to the reduction of the cardiovascular disease, prostate cancers, and maintaining the balance of acid and alkali in the body (Ejaz et al., 
2011), what's more its consumption is recommended for the digestive system enhancement, patients with arthritis and rheumatism particularly due to its high vitamin and mineral contents (Xie et al., 2007). Tomato production in Iran is estimated at 5 million and 800,000 tons annually which is $4.3 \%$ of the global production. In recent years, the average yield of tomato in Iran was about 25 tons ha ${ }^{-1}$ which is lower than the global average (Sajadi Nik et al., 2011). The most important reason for the reduction of the tomato production in Iran is related for the improper use of soil, inability to properly control pests and diseases, the absence of a suitable template and guide for consumption of organic fertilizers, and finally the recent water shortages in the country.

Using of organic fertilizers such as urban wet-waste compost and vermicompost is an appropriate method to increase and maintain the soil organic matters, improvement of depleted soil, and supplying the nutrients required by the plants (Mylavarapu and Zinati, 2009; Amiri et al., 2017). Composting is the method to convert the urban wet-waste to usable material that is produced by aerobic process and the organic matter recycling (Ahmadpour and Hosseinzadeh, 2017). The vermicompost is also produced by an earthworm from Lumbricidae family, during the non-thermal process and is used as the most important purifier and modifier of soil in agriculture and greenhouse cultures. This is due to its high-water holding capacity and humus materials (Hosseinzadeh et al., 2016). The humus material (humic acid and fulvic acid) are formed the $70 \%$ of soil organic matter, and have many nutritional elements that lead to increase the plants nutrients availability and their growth and functional properties (Cimrin and Yilmaz, 2005). The organic fertilizers such as compost and vermicompost play an important role in production of plant growth regulators such as auxin and cytokinin by increasing the microbial communities in the soil and the microorganisms' activity. During their growth, these materials cause to increase the height, number of lateral branches, leaf number, flowering, and production (Atiyeh et al., 2001; Amiri et al., 2017). Furthermore, the organic fertilizers lead to increase the stability of agriculture production because they have positive effects on the soil's physical properties including the permeability increasing, specific gravity (density) reduction, increasing the water holding capacity, improving the microbial activity and increasing the nutrient content in soil (Marinari et al., 2000; Huerta et al., 2010). In the study of the morphologic and functional properties of tomato, it is reported that vermicompost increased the soil enzymes activity especially phosphatase and urease. This increase will ultimately play an important role in yield and production improvement of tomato by increasing the available nutrient content (Yanga et al., 2015). In an experiment, researchers reported that adding an appropriate rate of vermicompost to the soil as well as by increasing the nutrient contents (especially nitrogen) caused to significant increase in the morphologic properties of beans, corn and peas (Samiran et al., 2010; Amiri et al., 2017). In the case of experimenting on the greenhouse cucumber, it was similarly reported that adding the urban wet-waste compost at all levels to the soil caused to significant increase of bush height, leaf number, and flower and fruit number in this plant (Dolgen et al., 2007). In the study of tomato, lettuce and pepper, it was observed that the 8 and $10 \%$ levels of urban-waste compost caused to increase the growth (bush height, root length, leaf number and lateral branch) and yield (dry weight of bush and product) in these plants (Wilson et al., 1989). Several studies on the urban-waste compost believe that it included a significant content of micro-elements which could form the organic chelates with organic matters which subsequently caused an increase in the solubility and absorbency of nutrients in soil (Lakhdar et al., 2009).

Organic fertilizers (compost and vermicompost) are the most appropriate alternative for chemical fertilizers and fungicides. These are considered as the best treatments in organic agriculture with the aim of producing the non-chemical productions. Considering the nutritional and economic value of tomato and whereas that choosing the substrate of this plant in greenhouse has special importance. This study was conducted to evaluate the organic matters effects on most important physiologic (i.e. relative water content, leaf cell membrane stability, chlorophyll a, b, carotenoids, total chlorophyll, and efficiency of photochemical performance of PSII) and morphologic (i.e. plant height, leaf number and area, leaf dry weight, root length and root dry weight) parameters. The main aim of this study was therefore the selecting the appropriate fertilizer to culture this plant in the greenhouse condition. 


\section{Materials and Methods}

In order to evaluate the organic fertilizers effects on tomato morpho-physiologic indices, an experiment was conducted as factorial based on a completely randomized design (CRD) with three replications in Behbahan Khatam Alanbia University of Technology. The studied treatments included: a) vermicompost and soil in four levels, 0:100 $\left(\mathrm{V}_{1}\right)$, 10:90 $\left(\mathrm{V}_{2}\right), 20: 80\left(\mathrm{~V}_{3}\right)$, and 30:70 $\left(\mathrm{V}_{4}\right) \mathrm{Wt} \%$ (respectively, was equivalent to 0:2500 g, 250:2250 g, 500:2000 g, and 750:1750 g). b) the different ratios of urban wet waste compost and soil in 4 levels 0:100 $\left(\mathrm{C}_{1}\right), 10: 90\left(\mathrm{C}_{2}\right), 20: 80\left(\mathrm{C}_{3}\right)$, and 30:70 (C4) Wt \% (respectively, was equivalent to 0:2500 g, 250:2250 g, 500:2000 g, and 750:1750 g). The properties of applied soil and fertilizers are shown in Table 1.

Table 1. Chemical characteristics of vermicompost, compost and soil

\begin{tabular}{|c|c|c|c|c|c|c|c|c|c|}
\hline Sample & $\begin{array}{c}\mathrm{EC} \\
\left(\mathrm{ds} \mathrm{m}^{-1}\right)\end{array}$ & $\mathrm{pH}$ & $\mathrm{C} / \mathrm{N}$ & $\begin{array}{c}\mathrm{P} \\
(\%)\end{array}$ & $\begin{array}{c}\mathrm{Ca} \\
(\%)\end{array}$ & $\begin{array}{c}\mathrm{K} \\
(\%)\end{array}$ & $\begin{array}{c}\mathrm{Fe} \\
(\%)\end{array}$ & $\begin{array}{c}\text { Total N } \\
(\%)\end{array}$ & $\begin{array}{c}\mathrm{Mg} \\
(\%)\end{array}$ \\
\hline Vermicompost & 1.3 & 7.1 & 12.8 & 1.5 & 4.5 & 1.6 & 0.5 & 1.9 & 0.5 \\
\hline Soil & 0.4 & 7.5 & 15.1 & 0.03 & 1.2 & 0.4 & 0.012 & 0.5 & 0.01 \\
\hline Compost & 2.5 & 7.9 & 21.1 & 1.3 & 5.5 & 1.5 & 0.6 & 1.5 & 1.3 \\
\hline
\end{tabular}

The compost and vermicompost was prepared from Arman Karan Zobde CO in Tehran. Each pot with $2.5 \mathrm{Kg}$ capacity of soil was considered as an experimental unit in which the tomato culture was done along with preparation of mentioned fertilizers and soil ratios. The used tomato variety was the Mobil cultivar and was provided from Pakan Bazr CO. from the city of Isfahan. The 300 homogeneous and monotonous seeds were selected and placed in a petri dish that was covered with filter paper, after 4 days, the seeds germinated and the basis of germination was emerging the radical (embryonic root) and hypocotyl (young shoot) from seeds. The embryo (little seedlings) having a duration of 4 days lifetime (the two-leaf embryos was selected equally) was transferred to the 48 pot, and places in the greenhouse conditions $\left(25^{\circ} \mathrm{C}\right.$ in days and $20^{\circ} \mathrm{C}$ in nights, 12 hours light and 12 hours darkness). Irrigation of plants was then carried out once every two days by weighing the pots at the field capacity level until the end of the experiment. In addition to regular irrigation of the pots they were all fed weekly with $150 \mathrm{ml}$ Hoagland solution for 4 weeks in order to increase the strength and proper establishment of seedlings. Since the main aim of this experiment was to study the physiological and morphological properties, which are the basis of yield and plants functional components, the harvesting of plants was thus done 50 days after culturing.

Measurement of morphological parameters: after harvesting the plants, the number of leaves in each pot was counted. To measure the height of the bush, a measuring ruler was used. To measure the dry weight of root and leaf, the samples were dried in an oven for 48 hours and $72{ }^{\circ} \mathrm{C}$, and then the dry weight was measured by using a digital scale (with precision 0.001 ). The leaf area was determined by leaf area measurement device as portable and the second, third and fourth leaves were selected for measurement (KR3000; Leaf Area Meter; Korea Tech Inc Suwon., Korea).

\section{Measurement of relative water contents, cell membrane stability, and PSII efficiency $\left(F_{v} / F_{m}\right)$}

In order to measure the relative water contents, the Bian and Jiang (2008) method was applied. The 0.5 $\mathrm{g}$ leaf was harvested from each treatment and was soaked in water for 48 hours. Then leaves were brought out from the water and their surfaces were dried using a tissue paper and then their weight was noted. After that, these leaves were dried in an oven for 48 hours after which they were weighted again. By measuring the above weight indices, via equation (1), this characteristic was determined for each treatment.

$$
\text { Equation (1) } \quad R W C=\frac{F W-D W}{T W-D W} \times 100
$$

In this equation, the RWC is relative water content, FW is fresh weight of leaf, DW is dry weight of leaf, TW is the weight of leaf in complete turgescent. 
In order to measure the leaf cell membrane stability a $0.2 \mathrm{~g}$ leaf was harvested from each treatment, and placed in two groups of test tube containing $10 \mathrm{ml}$ of distilled water. One group of the test tube was placed in $40{ }^{\circ} \mathrm{C}$ water bath (Model WNB 14, Memmert Instrument, Germany) for 30 minutes and another group was placed in $100^{\circ} \mathrm{C}$ water bath for 10 minutes. After reducing the tubes temperature to ambient temperature, the samples electrical conductivity is determined by electric conductivity meter (Model RS232, AZ Instrument Corp, Taiwan), and then according to the equation (2), this index was calculated by Sairam and Saxena (2001) method.

Equation (2)

$$
M S I=1-\frac{E C \text { of water in } 40^{\circ} \mathrm{C}}{E C \text { of } \text { water in } 100^{\circ} \mathrm{C}}
$$

The photochemical efficiency of PSII $\left(\mathrm{F}_{\mathrm{v}} / \mathrm{F}_{\mathrm{m}}\right)$, was determined by Chlorophyll fluorometer (Pocket PEA, Hansatech, Instruments Ltd., King's Lynn, Norfolk, England). The measurement was done by using special clips of the device that puts the leaves surface in darkness condition for 20 minutes. After this time, the $\mathrm{F}_{\mathrm{v}} / \mathrm{F}_{\mathrm{m}}$ was read automatically 6 times for each treatment, by connecting the interface of device to special clips and the total mean was recorded as a desired amount

\section{Measure of photosynthetic pigments}

To measure the photosynthetic pigments (chlorophyll a, b and carotenoid), the Lichtenthaler and Welburn method (1983) was applied. In order to observe the monotonously condition for all treatments, the third and fourth leaves of the seedlings were selected. The $0.1 \mathrm{~g}$ leaf was then pulverized in a mortar with $4 \mathrm{ml}$ acetone $80 \%$. The obtained solution was then centrifuged in $3000 \mathrm{rpm}$ for 5 minutes, and then in order to determine the chlorophyll and carotenoid, the absorption of supernatant was read by spectrophotometer (SPEKOL 2000; Analytic Jena, Germany) in 647, 664, $470 \mathrm{~nm}$ wavelength. To reset the device, acetone $80 \%$ was used. The total content of chlorophyll, chlorophyll $\mathrm{a}$ and $\mathrm{b}$, and carotenoid was calculated by equations (1) to $(4)$ :

$$
\begin{array}{ll}
\text { Equation (1) } & \operatorname{Chl}_{a}=12.21\left(A_{664}\right)-2.79\left(A_{647}\right) \\
\text { Equation (2) } & C h l_{b}=21.21\left(A_{647}\right)-5.1\left(A_{664}\right) \\
\text { Equation (3) } & \text { Carotenoid }=\frac{1000 A_{470}-1.8 C h l_{a}-85.02 \mathrm{Chl}_{b}}{198} \\
\text { Equation (4) } & C h l_{T}=C h l_{a}+\operatorname{Chl}_{b}
\end{array}
$$

All data were statistically analysed using factorial ANOVA test (MSTAT-C Version 4). Duncan's multiple range tests by using MSTAT-C software was performed to confirm the variability of results and for the determination of significant $(\mathrm{P} \leq 0.05)$ difference between the treatment groups.

\section{Results and discussion}

\section{Morphological traits}

The data analysis of variance showed that the compost and vermicompost as organic fertilizers had separately significant effect on all the studied morphologic traits. The interaction of these two treatments on plant height, dry weight of leaf, and root length was significant in confidence level of 95\% (Table 2). The compare means of compost and vermicompost effects on bush height indicated that by increasing the levels of compost and vermicompost, the plant height also increased significantly, so that the $\mathrm{V}_{4} \mathrm{C}_{4}$ and $\mathrm{V}_{3} \mathrm{C}_{4}$ had the most value of plant height, except $\mathrm{V}_{3} \mathrm{C}_{3}$ and $\mathrm{V}_{4} \mathrm{C}_{3}$ levels, this parameter increased significantly in all levels of $\mathrm{C}$ and $\mathrm{V}$. The lowest value of plant height was observed in $\mathrm{V}_{1} \mathrm{C}_{1}(102 \mathrm{~cm})$ and had no significant difference with $\mathrm{V}_{1} \mathrm{C}_{2}$ and $\mathrm{V}_{2} \mathrm{C}_{1}$ (106 and $103.7 \mathrm{~cm}$, respectively) (Table 5). The results on Table 3 showed that the leaf area with vermicompost treatments $(10,20$, and $30 \mathrm{wt} \%)$ had significant increase compared to control. The levels 
of the urban wet-waste compost, the 20 and $30 \mathrm{wt} \%$ levels, increased leaf area significantly in compared with control and $10 \mathrm{wt} \%$ level (Table 4). The results of compare relates to the simple effects of vermicompost on leaf number in which showed that 20 and $30 \mathrm{wt} \%$ levels (20 and 20.5 leaves number, respectively) had significant effect on this parameter compared to control and $10 \mathrm{wt} \%$ level (Table 3). In comparison of the studied compost levels, the results showed that $30 \mathrm{wt} \%$ treatments had the highest number of leaves (20.33) which had the most significant increase in comparison with control and $10 \mathrm{wt} \%$ treatments (Table 4). In studying the interaction of compost and vermicompost on dry weight of leaf the results showed that $\mathrm{V}_{4} \mathrm{C}_{4}$ treatment had most dry weight of leaf with $2.63 \mathrm{~g}$ weight, and had no significant difference with $\mathrm{V}_{4} \mathrm{C}_{3}$ with $2.40 \mathrm{~g}$ weight, but had significant increase compared to other studied treatments. The lowest value of dry weight of leaf was dedicated to $\mathrm{V}_{1} \mathrm{C}_{1}$ treatment $(1.10 \mathrm{~g})$, and had significant decrease in comparison with other levels except $\mathrm{V}_{1} \mathrm{C}_{2}$ and $\mathrm{V}_{2} \mathrm{C}_{1}$ (Table 5). The data compare mean of root length showed that $\mathrm{V}_{4} \mathrm{C}_{4}$ and $\mathrm{V}_{3} \mathrm{C}_{4}$ treatments increased the root length significantly compared to other treatments; also, the lowest root length was belonged to $V_{1} C_{1}$ treatment $(12.80 \mathrm{~cm})$ and had no significant difference in comparison with $\mathrm{V}_{1} \mathrm{C}_{2}, \mathrm{~V}_{1} \mathrm{C}_{3}$, $\mathrm{V}_{1} \mathrm{C}_{4}$ and $\mathrm{V}_{2} \mathrm{C}_{1}$ treatments (Table 5). The results of the compare means regarding the simple effects of vermicompost on root dry weight showed that studied vermicompost treatments in this experiment $(10,20$, and $30 \mathrm{wt} \%$ ) caused to significant increase of this parameter in comparison with control, so that between vermicompost treatments, treatment of $30 \mathrm{wt} \%$ increased the root dry weight significantly compared to treatments of 10 and $20 \mathrm{wt} \%$ (Table 3). In evaluation of simple effects of urban-wet waste compost, the results also showed that treatments of 10,20 , and $30 \mathrm{wt} \%$ increased the root dry weight $(4.19,4.38$, and $4.66 \mathrm{~g}$, respectively) significantly compared to control (Table 4).

Table 2. Analysis of variance of morphological features of tomato in different levels of vermicompost and compost fertilizers

\begin{tabular}{|c|c|c|c|c|c|c|c|}
\hline S.O.V & $\begin{array}{c}\text { Degree } \\
\text { of } \\
\text { freedom }\end{array}$ & $\begin{array}{c}\text { Plant } \\
\text { height }\end{array}$ & \multicolumn{1}{c|}{$\begin{array}{c}\text { Leaf } \\
\text { area }\end{array}$} & $\begin{array}{c}\text { Number of } \\
\text { leaves }\end{array}$ & $\begin{array}{c}\text { Leaf dry } \\
\text { weight }\end{array}$ & $\begin{array}{c}\text { Root } \\
\text { length }\end{array}$ & $\begin{array}{c}\text { Root dry } \\
\text { weight }\end{array}$ \\
\hline \multicolumn{7}{|c|}{ Mean Square } \\
\hline Vermicompost & 3 & $296.965^{*}$ & $3703.833^{* *}$ & $43.500^{* *}$ & $1.164^{* *}$ & $31.876^{* *}$ & $1.318^{* *}$ \\
\hline Compost & 3 & $275.410^{* *}$ & $2055.389^{* *}$ & $55.556^{* *}$ & $1.701^{*}$ & $14.745^{* *}$ & $1.328^{* *}$ \\
\hline V $\times$ C & 9 & $6.132^{*}$ & $35.963^{\text {ns }}$ & $2.907^{\text {ns }}$ & $0.049^{*}$ & $1.078^{*}$ & $0.070^{*}$ \\
\hline Error & 32 & 8.583 & 63.917 & 3.521 & 0.022 & 0.480 & 0.051 \\
\hline
\end{tabular}

${ }^{\mathrm{n}}$ : non-significant, " and ": significant at $\mathrm{P} \leq 0.05$ and $\mathrm{P} \leq 0.01$, respectively

Table 3. Effects of vermicompost fertilizer on morphological features of tomato

\begin{tabular}{|c|c|c|c|}
\hline Vermicompost treatments & Leaf area $\left(\mathrm{cm}^{2}\right)$ & Number of leaves & Root dry weight $(\mathrm{g})$ \\
\hline Control & $264.8 \mathrm{c}$ & $16.50 \mathrm{~b}$ & $3.85 \mathrm{c}$ \\
\hline $10 \%$ & $280.1 \mathrm{~b}$ & $17.25 \mathrm{~b}$ & $4.26 \mathrm{~b}$ \\
\hline $20 \%$ & $299.8 \mathrm{a}$ & $20.25 \mathrm{a}$ & $4.32 \mathrm{~b}$ \\
\hline $30 \%$ & $301.9 \mathrm{a}$ & $20 \mathrm{a}$ & $4.66 \mathrm{a}$ \\
\hline
\end{tabular}

Difference between data of each column followed by the same letter was not statistically significant $(\mathrm{p}<0.05)$

Table 4. Effects of compost fertilizer on morphological features of tomato

\begin{tabular}{|c|c|c|c|}
\hline Compost treatments & $\begin{array}{c}\text { Leaf area } \\
\left(\mathrm{cm}^{2}\right)\end{array}$ & $\begin{array}{c}\text { Number of } \\
\text { leaves }\end{array}$ & $\begin{array}{c}\text { Root dry weight } \\
(\mathrm{g})\end{array}$ \\
\hline Control & $274.9 \mathrm{c}$ & $15.67 \mathrm{c}$ & $3.87 \mathrm{c}$ \\
\hline $10 \%$ & $277.5 \mathrm{c}$ & $18 \mathrm{~b}$ & $4.19 \mathrm{~b}$ \\
\hline $20 \%$ & $291.1 \mathrm{~b}$ & $20 \mathrm{ab}$ & $4.38 \mathrm{~b}$ \\
\hline $30 \%$ & $303.2 \mathrm{a}$ & $20.33 \mathrm{a}$ & $4.66 \mathrm{a}$ \\
\hline
\end{tabular}

Difference between data of each column followed by the same letter was not statistically significant $(p<0.05)$ 
Table 5. Effects of vermicompost and compost fertilizer on morphological features of tomato

\begin{tabular}{|c|c|c|c|c|}
\hline $\begin{array}{c}\text { Vermicompost } \\
\text { treatments }\end{array}$ & $\begin{array}{l}\text { Compost } \\
\text { treatments }\end{array}$ & $\begin{array}{c}\text { Plant height } \\
(\mathrm{cm})\end{array}$ & $\begin{array}{l}\text { Leaf dry weight } \\
\text { (g) }\end{array}$ & $\begin{array}{l}\text { Root length } \\
(\mathrm{cm})\end{array}$ \\
\hline \multirow{4}{*}{ Control $\left(V_{1}\right)$} & Control $\left(\mathrm{C}_{1}\right)$ & $102 \mathrm{~g}$ & $1.10 \mathrm{~h}$ & $12.80 \mathrm{~h}$ \\
\hline & $10 \%\left(\mathrm{C}_{2}\right)$ & $106 \mathrm{fg}$ & $1.30 \mathrm{fgh}$ & $13.37 \mathrm{gh}$ \\
\hline & $20 \%\left(\mathrm{C}_{3}\right)$ & $111.3 \mathrm{cde}$ & $1.53 \mathrm{def}$ & $14.03 \mathrm{efgh}$ \\
\hline & $30 \%\left(\mathrm{C}_{4}\right)$ & $115.7 \mathrm{bcd}$ & $1.63 \mathrm{de}$ & $13.97 \mathrm{fgh}$ \\
\hline \multirow{4}{*}{$10 \%\left(\mathrm{~V}_{2}\right)$} & Control $\left(\mathrm{C}_{1}\right)$ & $103.7 \mathrm{~g}$ & $1.16 \mathrm{gh}$ & $13.47 \mathrm{gh}$ \\
\hline & $10 \%\left(\mathrm{C}_{2}\right)$ & $109.7 \mathrm{ef}$ & $1.40 \mathrm{efg}$ & $14.17 \mathrm{efg}$ \\
\hline & $20 \%\left(C_{3}\right)$ & $110.3 \mathrm{def}$ & $1.73 \mathrm{~d}$ & $14.83 \mathrm{def}$ \\
\hline & $30 \%\left(\mathrm{C}_{4}\right)$ & $116.3 \mathrm{bc}$ & $2.10 \mathrm{c}$ & $15.30 \mathrm{cde}$ \\
\hline \multirow{4}{*}{$20 \%\left(V_{3}\right)$} & Control $\left(\mathrm{C}_{1}\right)$ & $112.3 \mathrm{cde}$ & $1.56 \mathrm{def}$ & $14.33 \mathrm{efg}$ \\
\hline & $10 \%\left(\mathrm{C}_{2}\right)$ & $115.3 \mathrm{bcd}$ & $1.53 \mathrm{def}$ & $15.77 \mathrm{~cd}$ \\
\hline & $20 \%\left(C_{3}\right)$ & $120 \mathrm{ab}$ & $2.13 \mathrm{c}$ & $16.53 \mathrm{bc}$ \\
\hline & $30 \%\left(\mathrm{C}_{4}\right)$ & $122 \mathrm{a}$ & $2.30 \mathrm{bc}$ & $17.30 \mathrm{~b}$ \\
\hline \multirow{4}{*}{$30 \%\left(V_{4}\right)$} & Control $\left(\mathrm{C}_{1}\right)$ & 115 bcde & $1.66 \mathrm{de}$ & $15.03 \mathrm{def}$ \\
\hline & $10 \%\left(\mathrm{C}_{2}\right)$ & $115.3 \mathrm{bcd}$ & $1.70 \mathrm{~d}$ & $16.33 \mathrm{bc}$ \\
\hline & $20 \%\left(C_{3}\right)$ & $a b 119 a b$ & $2.40 \mathrm{ab}$ & $18.80 \mathrm{a}$ \\
\hline & $30 \%\left(\mathrm{C}_{4}\right)$ & $123.3 \mathrm{a}$ & $2.63 \mathrm{a}$ & $18.70 \mathrm{a}$ \\
\hline
\end{tabular}

Difference between data of each column followed by the same letter was not statistically significant $(\mathrm{p}<0.05)$

Increasing the plant height indicates that the plant steam capacity is increased as secondary source to store the photosynthetic material, and increasing the leaf area shows the more photosynthetic capacity (Amiri et al., 2017). Organic fertilizers especially vermicompost have humic acid, fulvic acid and other organic acids that are produced by microorganisms and can stimulate the growth and germination of plants (Hosseinzadeh and Ahmadpour, 2018). On the other hand, several studies have reported that adding compost and vermicompost to the soil has caused to produce a substance similar to auxin (Bender Ozenç, 2006; Archana et al., 2009; Beyk Khurmizi et al., 2016). These researchers state that organic fertilizers are rich in nutritious elements including zinc and this element plays important role in structure of Tryptophan Amino Acid (the main precursor to the auxin synthesis). Therefore, by increasing several of the growth indices such as plant height, leaf area, leaf number, and dry weight of leaf affected by using the vermicompost and urban wet-waste compost can be attributed to the presence of plant growth regulators such as auxin. The main role of auxin is acidic growth increasing in cell walls that finally leads to increase the longitudinal growth of the plant. The other role of auxin hormone includes a delay in leaf and stem senescence, reproductive stage regulation especially the seeds and fruits development, accelerating the lateral roots formation that play an important role in increasing the water and nutrients absorption in the plant (Ahmadpour and Hosseinzadeh, 2017; Amiri et al., 2017). In other studies of other plants such as radish (Raphanus sativus), cabbage rapa (Brassica rapa), tomato (Lycopersicon esculentum) and cucumber (Cucumis sativus), it was observed that the use of organic fertilizers (such as vermicompost and compost) had a positive and significant effect on the growth indices (such as bush height, leaf area, root area and bush dry weight) (Bender Ozenç, 2006; Dolgen et al., 2007; Archana et al., 2009; Warman and AngLopez, 2010). Due to the direct relationship between photosynthesis and dry matter yield (Rahbarian et al., 2011), increasing the leaf and root dry weight at high levels of urban-wet waste compost and vermicompost seems logical. In this field, other researches also reported increasing the bush height, root length, and dry weight of cucumber (Sallaku et al., 2009), strawberry (Arancon et al., 2004), and oat (Atiyeh et al., 2001) if using vermicompost. In the study of the effects of urban wet waste compost on tomato, lettuce, pepper (Wilson et al., 1989) and lentil (Ahmadpour and Hosseinzadeh, 2017), it was observed that the different levels of studied compost resulted in growth increasing (plant height, root length, leaf number) and yield (dry weight of the bush, and product) in these plants. 
Relative water content $(R W C)$, membrane stability index (MSI) and photochemical performance of PSII $\left(F_{v} / F_{m}\right)$

The data analyses of variance showed that simple and interaction effects of treatments (compost and vermicompost) were significant on the plant's RWC, MSI and $F_{v} / F_{m}$ (Table 6). The compare means of data showed that most value of RWC was dedicated to $\mathrm{V}_{4} \mathrm{C}_{4}$ treatment and had no significant difference with $\mathrm{V}_{3} \mathrm{C}_{3}$, $\mathrm{V}_{3} \mathrm{C}_{4}, \mathrm{~V}_{4} \mathrm{C}_{3}$ treatments. The lowest value of this parameter was observed in $\mathrm{V}_{1} \mathrm{C}_{1}$ treatment, which had no significant difference with $\mathrm{V}_{1} \mathrm{C}_{2}, \mathrm{~V}_{1} \mathrm{C}_{3}$ and $\mathrm{V}_{2} \mathrm{C}_{1}$ treatments (Table 7). The results that related to the interactions between the use of urban wet-waste compost and vermicompost on MSI indicated that $\mathrm{V}_{4} \mathrm{C}_{4}$ had highest-value of MSI that had significant increase in comparison with other treatments except $\mathrm{V}_{4} \mathrm{C}_{3}$. The $\mathrm{V}_{2} \mathrm{C}_{1}$ treatment had lowest value of MSI, and statically had no significant difference with $V_{1} C_{1}, V_{1} C_{2}, V_{1} C_{3}$ treatments (Table 7). The results showed that $\mathrm{F}_{\mathrm{v}} / \mathrm{F}_{\mathrm{m}}$ had significant increase when compost and vermicompost levels were increased. The $\mathrm{V}_{4} \mathrm{C}_{4}, \mathrm{~V}_{4} \mathrm{C}_{3}$, and $\mathrm{V}_{3} \mathrm{C}_{4}$ had most value of $\mathrm{F}_{\mathrm{v}} / \mathrm{F}_{\mathrm{m}}$ statically, that compared to other treatments this increase was significant. By decreasing the compost and vermicompost levels $\left(\mathrm{V}_{1} \mathrm{C}_{1}, \mathrm{~V}_{1} \mathrm{C}_{2}\right.$, $\mathrm{V}_{2} \mathrm{C}_{1}$ ) the value of $\mathrm{F}_{\mathrm{v}} / \mathrm{F}_{\mathrm{m}}$ reduced significantly (Table 7 ).

Table 6. Analysis of variance of physiological features of tomato in different levels of vermicompost and compost fertilizers under water stress

\begin{tabular}{|c|c|c|c|c|c|c|c|c|}
\hline S.O.V & Df & $\begin{array}{c}\text { Relative water } \\
\text { content } \\
(\%)\end{array}$ & $\begin{array}{c}\text { Membrane } \\
\text { stability index } \\
(\%)\end{array}$ & $\mathrm{F}_{\mathrm{v}} / \mathrm{F}_{\mathrm{m}}$ & Chl a & Chl b & $\begin{array}{c}\text { Carote- } \\
\text { noid }\end{array}$ & $\begin{array}{c}\text { Total Chl } \\
\text { content }\end{array}$ \\
\hline & \multicolumn{7}{|c|}{ Mean square } & \\
\hline Vermicompost & 3 & $0.009^{* *}$ & $0.008^{* *}$ & $0.007^{* *}$ & $2.586^{*}$ & $0.021^{* *}$ & $0.014^{*}$ & $3.039^{* *}$ \\
\hline Compost & 3 & $0.007^{* *}$ & $0.007^{* *}$ & $0.009^{* *}$ & $0.492^{* *}$ & $0.060^{* *}$ & $0.087^{* *}$ & $0.880^{* *}$ \\
\hline $\mathrm{V} \times \mathrm{C}$ & 9 & $0.0003^{*}$ & $0.001^{*}$ & $0.0004^{* *}$ & $0.046^{*}$ & $0.003^{\mathrm{ns}}$ & $0.001^{\mathrm{ns}}$ & $0.051^{\mathrm{ns}}$ \\
\hline Error & 32 & 8.583 & 0.00002 & 0.0001 & 4.82 & 0.001 & 0.004 & 0.025 \\
\hline \multicolumn{9}{|c|}{${ }^{\mathrm{ns}}$ : non-significant, "and ": significant at $\mathrm{P} \leq 0.05$ and $\mathrm{P} \leq 0.01$, respectively } \\
\hline
\end{tabular}

Table 7. Effects of vermicompost and compost fertilizer on physiological features of tomato

\begin{tabular}{|c|c|c|c|c|c|}
\hline $\begin{array}{c}\text { Vermicompost } \\
\text { treatments }\end{array}$ & $\begin{array}{c}\text { Compost } \\
\text { treatments }\end{array}$ & $\begin{array}{c}\text { Relative Water } \\
\text { Content } \\
(\%)\end{array}$ & $\begin{array}{c}\text { Membrane } \\
\text { Stability index } \\
(\%)\end{array}$ & $\mathrm{F}_{\mathrm{v}} / \mathrm{F}_{\mathrm{m}}$ & $\begin{array}{c}\text { Chl a } \\
\left(\mathrm{mg} / \mathrm{g}^{-1} \mathrm{FW}\right)\end{array}$ \\
\hline \multirow{5}{*}{ Control $\left(\mathrm{V}_{1}\right)$} & Control $\left(\mathrm{C}_{1}\right)$ & $0.733 \mathrm{~h}$ & $0.537 \mathrm{jk}$ & $0.686 \mathrm{~g}$ & $2.20 \mathrm{~h}$ \\
\cline { 2 - 6 } & $10 \%\left(\mathrm{C}_{2}\right)$ & $0.739 \mathrm{~h}$ & $0.538 \mathrm{jk}$ & $\mathrm{fg} 0.699$ & $2.41 \mathrm{gh}$ \\
\cline { 2 - 6 } & $20 \%\left(\mathrm{C}_{3}\right)$ & $0.748 \mathrm{gh}$ & $0.540 \mathrm{ijk}$ & $0.717 \mathrm{ef}$ & $2.45 \mathrm{gh}$ \\
\cline { 2 - 6 } & $30 \%\left(\mathrm{C}_{4}\right)$ & $0.765 \mathrm{efg}$ & $0.549 \mathrm{hi}$ & $0.714 \mathrm{ef}$ & $2.52 \mathrm{fg}$ \\
\hline \multirow{3}{*}{$10 \%\left(\mathrm{~V}_{2}\right)$} & Control $\left(\mathrm{C}_{1}\right)$ & $0.737 \mathrm{~h}$ & $0.535 \mathrm{k}$ & $0.702 \mathrm{fg}$ & $2.43 \mathrm{gh}$ \\
\cline { 2 - 6 } & $10 \%\left(\mathrm{C}_{2}\right)$ & $0.762 \mathrm{fg}$ & $0.556 \mathrm{gh}$ & ef 0.722 & $2.83 \mathrm{de}$ \\
\cline { 2 - 6 } & $20 \%\left(\mathrm{C}_{3}\right)$ & $0.782 \mathrm{de}$ & $0.565 \mathrm{fg}$ & $0.756 \mathrm{bc}$ & $2.97 \mathrm{cde}$ \\
\cline { 2 - 6 } & $30 \%\left(\mathrm{C}_{4}\right)$ & $0.790 \mathrm{~cd}$ & $0.582 \mathrm{~g}$ & $0.761 \mathrm{~b}$ & $3.04 \mathrm{~cd}$ \\
\cline { 2 - 6 } & Control $\left(\mathrm{C}_{1}\right)$ & $0.751 \mathrm{fgh}$ & $0.551 \mathrm{~h}$ & $0.727 \mathrm{de}$ & $2.76 \mathrm{ef}$ \\
\cline { 2 - 6 } & $10 \%\left(\mathrm{C}_{2}\right)$ & $0.781 \mathrm{de}$ & ef 0.568 & $0.730 \mathrm{de}$ & $3.19 \mathrm{bc}$ \\
\cline { 2 - 6 } & $20 \%\left(\mathrm{C}_{3}\right)$ & $0.812 \mathrm{ab}$ & $0.621 \mathrm{bc}$ & $0.750 \mathrm{bcd}$ & $3.49 \mathrm{a}$ \\
\cline { 2 - 6 } & $30 \%\left(\mathrm{C}_{4}\right)$ & $0.825 \mathrm{a}$ & $0.612 \mathrm{c}$ & $0.782 \mathrm{a}$ & $3.42 \mathrm{ab}$ \\
\hline \multirow{3}{*}{$30 \%\left(\mathrm{~V}_{4}\right)$} & Control $\left(\mathrm{C}_{1}\right)$ & $0.768 \mathrm{ef}$ & $0.546 \mathrm{hij}$ & $0.734 \mathrm{cde}$ & $3.35 \mathrm{ab}$ \\
\cline { 2 - 6 } & $10 \%\left(\mathrm{C}_{2}\right)$ & $0.806 \mathrm{bc}$ & de 0.578 & $0.737 \mathrm{cde}$ & $3.46 \mathrm{ab}$ \\
\cline { 2 - 6 } & $20 \%\left(\mathrm{C}_{3}\right)$ & $0.825 \mathrm{a}$ & $0.628 \mathrm{ab}$ & $0.781 \mathrm{a}$ & $3.46 \mathrm{ab}$ \\
\cline { 2 - 6 } & $30 \%\left(\mathrm{C}_{4}\right)$ & $0.827 \mathrm{a}$ & $0.637 \mathrm{a}$ & $0.785 \mathrm{a}$ & $3.54 \mathrm{a}$ \\
\hline
\end{tabular}


The relative water content is considered as the most important physiological indices in greenhouse plants. In fact, the more value of this parameter indicates the leaf ability in maintain the more water content, photosynthetic process, and transferring the material in aerial organs or shoots (Sanchez-Rodriguez et al., 2010). Improvement of physical properties of soil such as high-water holding capacity, cation exchange capacity, increasing the organic matter (humic and fulvic acids), and creating suitable conditions for photosynthesis are of considerable properties of organic fertilizers (Ahmadpour and Bahrami, 2016; Amiri et al., 2017). Humic acid and fulvic acid play an important role in increasing the plant physiological properties (relative water content and membrane stability), by increasing the beneficial microorganisms activity, increasing the enzymatic activity, releasing the nutrients, improvement the root growth by amending the physical structure of the soil directly, and by improvement soil properties such as aggregation, ventilation, permeability and transmission of micro-elements indirectly (Tan, 2003; Hosseinzadeh et al., 2016). Using these fertilizers causes to relative increase of water potential in cell roots and maintaining the water transmission path in the xylem from the root to the shoots, in addition to increase the available water in the root (Chanda et al., 2011; Amiri et al., 2017). In recent studies of plant Eco-physiology studies, $\mathrm{F}_{\mathrm{v}} / \mathrm{F}_{\mathrm{m}}$ has been considered as a rapid, sensitive, and non-destructive method and is suitable index to measure the plant photosynthetic efficiency (Rasti Sani et al., 2014). The several studies about compost and vermicompost showed that using of these fertilizers can be effective in maintain the photosynthetic activity and PSII performance (as a first light system involved in the photosynthetic electron transfer chain) (Bender Ozenç, 2006; Hosseinzadeh et al., 2016). These researchers demonstrated that adding the organic fertilizers (such as compost and vermicompost) to soil causes to less stomata closure, $\mathrm{CO}_{2}$ increasing inside the cell, maintaining the passive transmission in xylem, increasing the carboxylase activity of Rubisco enzyme, by increasing the water holding capacity, root growth, and nutrient elements.

\section{Photosynthetic pigments}

The effect of urban wet-waste compost and vermicompost on chlorophyll (Chl) a, b, carotenoids and total chlorophyll content was significant, but the interaction effect of these treatments only had significant effect on chlorophyll a content (Table 6). The data compare means that the interaction effects of compost and vermicompost on $\mathrm{Chl}$ a had the highest value of $\mathrm{Chl}$ a observed in $\mathrm{V}_{4} \mathrm{C}_{4}$ treatment that had no significant difference in comparison with $\mathrm{V}_{4} \mathrm{C}_{1}, \mathrm{~V}_{4} \mathrm{C}_{2}, \mathrm{~V}_{4} \mathrm{C}_{3}, \mathrm{~V}_{3} \mathrm{C}_{3}$, and $\mathrm{V}_{3} \mathrm{C}_{4}$ treatments. The lowest value of this parameter was observed in $\mathrm{V}_{1} \mathrm{C}_{1}$ treatment which had a significant difference with other treatments except the $\mathrm{V}_{2} \mathrm{C}_{1}, \mathrm{~V}_{1} \mathrm{C}_{2}$ and $\mathrm{V}_{1} \mathrm{C}_{3}$ treatments (Table 7). In evaluation the simple effects of vermicompost (Table 8) the results showed that applying the 20 and $30 \mathrm{wt} \%$ of vermicompost caused to significant increase of Chl b compared to control and $10 \mathrm{wt} \%$ of vermicompost. Among the studied compost levels (Table 9), the results showed that increasing the used levels of urban wet-waste compost from 10 to $30 \mathrm{wt} \%$ led to significant increase in this parameter compared to control. The compare means of leaf carotenoid content indicated that this parameter had significant increase in $30 \mathrm{wt} \%$ of vermicompost in comparison with control and $10 \mathrm{wt} \%$ treatments (Table 8). In studying the simple effects of urban wet-waste compost, the results showed that leaf carotenoid content had significant increase affected by 20 and $30 \mathrm{wt} \%$ of compost compared to control and 10 wt\% (Table 9). The compare means results about the simple effects of vermicompost on total leaf Chl content $(\mathrm{a}+\mathrm{b})$ meanwhile showed that the highest and lowest values were dedicated to $30 \mathrm{wt} \%$ of vermicompost and control, respectively, that were significant compared to each other and other treatments (Table 8). Among the levels of urban wet-waste compost, the $30 \mathrm{wt} \%$ treatment had most value of total Chl that had no significant difference compared to $20 \mathrm{wt} \%$ treatment. The lowest value of total chlorophyll was dedicated to control and had significant difference with other treatments (Table 9). 
Table 8. Effects of vermicompost fertilizer on physiological features of tomato

\begin{tabular}{|c|c|c|c|}
\hline Vermicompost treatments & $\begin{array}{c}\text { Chl b } \\
\left(\mathrm{mg} / \mathrm{g}^{-1} \mathrm{FW}\right)\end{array}$ & $\begin{array}{c}\text { Carotenoid } \\
\left(\mathrm{mg} / \mathrm{g}^{-1} \mathrm{FW}\right)\end{array}$ & $\begin{array}{c}\text { Total Chl content } \\
\left(\mathrm{mg} / \mathrm{g}^{-1} \mathrm{FW}\right)\end{array}$ \\
\hline Control & $1.215 \mathrm{~b}$ & $2.301 \mathrm{~b}$ & $3.609 \mathrm{~d}$ \\
\hline $10 \%$ & $\mathrm{~b} 1.219$ & $2.300 \mathrm{~b}$ & $4.033 \mathrm{c}$ \\
\hline $20 \%$ & $1.297 \mathrm{a}$ & $2.338 \mathrm{ab}$ & $4.516 \mathrm{~b}$ \\
\hline $30 \%$ & $1.278 \mathrm{a}$ & $2.372 \mathrm{a}$ & $4.734 \mathrm{a}$ \\
\hline
\end{tabular}

Table 9. Effects of compost fertilizer on physiological features of tomato

\begin{tabular}{|c|c|c|c|}
\hline Compost treatments & $\begin{array}{c}\text { Chl b } \\
\left(\mathrm{mg} / \mathrm{g}^{-1} \mathrm{FW}\right)\end{array}$ & $\begin{array}{c}\text { Carotenoid } \\
\left(\mathrm{mg} / \mathrm{g}^{-1} \mathrm{FW}\right)\end{array}$ & $\begin{array}{c}\text { Total Chl content } \\
\left(\mathrm{mg} / \mathrm{g}^{-1} \mathrm{FW}\right)\end{array}$ \\
\hline Control & $1.167 \mathrm{~d}$ & $2.236 \mathrm{~b}$ & $3.850 \mathrm{c}$ \\
\hline $10 \%$ & $1.230 \mathrm{c}$ & $2.285 \mathrm{~b}$ & $4.207 \mathrm{~b}$ \\
\hline $20 \%$ & $1.281 \mathrm{~b}$ & $2.360 \mathrm{a}$ & $4.367 \mathrm{ab}$ \\
\hline $30 \%$ & $1.332 \mathrm{a}$ & $2.372 \mathrm{a}$ & $4.468 \mathrm{a}$ \\
\hline
\end{tabular}

Difference between data of each column followed by the same letter was not statistically significant $(p<0.05)$

The leaves photosynthetic pigmentation has an important role in the electron excitation in the photosynthetic electron transport chain and the producing the high-energy molecules (including ATP and NADPH) by taking the sunlight energy (Hosseinzadeh et al., 2016). Maintaining the photosynthetic process is dependent on receiving the energy and producing the high-energy molecules (Keles and Onsel, 2004). Therefore, in evaluating the different treatments on greenhouse plants in order to increase the yield and production, these parameters have more important. Several studies have shown that increasing the microorganism's activity by adding the compost and vermicompost to soil has main role in nitrogen fixation (Davison, 1988; Amiri et al., 2017). According to the nitrogen structure of porphyrin rings of Chl a and b, by increasing the chlorophyll content seems logical which includes using high levels of compost and vermicompost. Another advantage of terrestrial microorganisms' activity is that they lead to release the plants required elements such as zinc, iron, manganese, magnesium (main role in chlorophylls structure) and etc. by weathering the rocks and minerals that makes them available for plants (Ahmadpour and Hosseinzadeh, 2017).

In another study on the photosynthetic pigments, it is observed that chlorophylls are sensitive to light oxidation and inhibition, while the carotenoids role is as antioxidant and protector of chlorophylls. The chlorophyll content is usually proportional with carotenoid content that protects chlorophylls (Loggini et al., 1999). Hence, by increasing the total chlorophyll content in applied levels of organic fertilizers that compared to control can be attributed to the increase in the carotenoid's contents within these levels. Generally, it can be stated that adding the organic fertilizers such as compost and vermicompost to root ambient have a decisive role in maintaining the transfer water-soluble nutrients from the root to the leaf (through passive transmission in the xylem). This can be accomplished by increasing the macro-elements (Nitrogen, Phosphorus, Potassium, Calcium, Magnesium) and micro-elements (Iron, Zinc, Copper and Manganese), which in addition to the nourishment the leaf because of the leaf morphologic indices increasing (e.g. increasing the area and number of leaf), also have basic role in stability of photosynthetic pigments (via involving in the chlorophylls structure) and photosynthetic system (as a prosthetic group in activating some enzymes and proteins) (Mylavarapu and Zinati, 2009; Hosseinzadeh et al., 2016; Amiri et al., 2017).

\section{Conclusions}

The results of this study in association with simple effects of treatments on tomato showed that by using the vermicompost in $30 \mathrm{wt} \%$ level caused a significant increas of leaf area $(+12.28 \%)$, leaf number in bush 
$(+17.5 \%)$, root dry weight $(+17.3 \%)$, Chl b content $(4.9 \%)$, carotenoid $(+2.9 \%)$, and total Chl a $+\mathrm{b}(+23.7 \%)$. Among the levels of used urban wet-waste compost, 20 and $30 \mathrm{wt} \%$ levels had also significant increase in leaf area $(+5.5 \%,+9.33 \%$, respectively), leaf number in bush $(+21.6 \%,+22.9 \%)$, root dry weight $(+11.6 \%$, $+16.9 \%)$, Chl b content $(+8.8 \%,+12.3 \%)$, carotenoid $(+5.2 \%,+7.9 \%)$, and total Chl $\mathrm{a}+\mathrm{b}(+11.8 \%,+13.8 \%)$ compared to control. In evaluating the interaction effects of treatments, the results showed that the vermicompost and urban wet-waste compost mixture in $30 \mathrm{wt} \%$ level $\left(\mathrm{V}_{4} \mathrm{C}_{4}\right)$ had the highest value of plant height, leaf dry weight, root length, RWC, MSI, $\mathrm{F}_{\mathrm{v}} / \mathrm{F}_{\mathrm{m}}$ and $\mathrm{Chl}$ a content which had no significant difference with $\mathrm{V}_{4} \mathrm{C}_{3}$ treatment in all studied parameters. Considering that evaluated morphologic and physiologic characteristics in this experiment are the base of functional parameters, so increasing the mentioned properties can play an important role to increase the yield and production of the tomato. According to the results of this study, applying the vermicompost and urban wet-waste compost in $30 \mathrm{wt} \%$ level is recommended. This is recommended since it improves the morphologic and physiologic characteristics of the tomato in greenhouse conditions.

\section{Authors' Contributions}

All authors read and approved the final manuscript.

\section{Acknowledgements}

This research received no specific grant from any funding agency in the public, commercial, or not-forprofit sectors.

\section{Conflict of Interests}

The authors declare that there are no conflicts of interest related to this article.

\section{References}

Ahmadpour R, Bahrami T (2016). Influence foliar application of compost tea under water deficit stress of lentil plant by assessment of morphological parameters. Journal of Plant Physiology and Biochemistry 1(2):40-51.

Ahmadpour R, Hosseinzadeh SR (2017). Evaluating the effects of water stress and urban waste compost on morphophysiological indices and yield components of lentil (Lens culinaris Medik). Journal of Iranian Plant Echophysiological Research 12(46):42-56.

Amiri H, Ismaili A, Hosseinzadeh SR (2017). Influence of vermicompost fertilizer and water deficit stress on morphophysiological features of chickpea (Cicer arietinum L. cv. Karaj). Compost Science and Utilization 25(3):152-165. https://doi.org/10.1080/1065657X.2016.1249313

Arancon NQ, Edwards CA, Bierman P, Welch C, Metzger JD (2004). Influence of vermicompost on field strawberries. Bioresource Technology 93:145-153. https://doi.org/10.1016/j.biortech.2003.10.014

Archana PP, Theodore JKR, Ngyuen VH, Stephen TT (2009). Vermicompost extracts influence growth, mineral nutrients, phytonutrients and antioxidant activity in pak choi (Brassica rapa cv. Bonsai, Chinensis group) grown under vermicompost and chemical fertiliser. Journal of the Science of Food and Agriculture 89(1):2383-2392. https://doi.org/10.1002/jsfa.3732 
Atiyeh RM, Arancon NQ, Edwards CA, Metzger JD (2001). The influence of earthworm processed pig manure on the growth and productivity of marigolds. Bioresource Technology 81:103-108. https://doi.org/10.1016/S0960-8524(01)001225

Bender Özenç D (2006). Effects of composted hazelnut husk on growth of tomato plants. Compost Science and Utilization 14:271-275. https://doi.org/10.1080/1065657X.2006.10702296

Beyk Khurmizi A, Abrishamchi P, Ganjeali A, Parsa M (2016). Effect of vermicompost on some morphological, physiological and biochemical traits of bean (Phaseolus vulgaris L.) under salinity stress. Journal of Plant Nutrition 39(6):883-893. https://doi.org/10.1080/01904167.2015.1109104

Bian Sh, Jiang Y (2008). Reactive oxygen species, antioxidant enzyme activities and gene expression patterns in leaves and roots of Kentucky bluegrass in response to drought stress and recovery. Scientia Horticulturae 120:264-270. https://doi.org/10.1016/j.scienta.2008.10.014

Cimrin MK, Yilmaz I (2005). Humic acid application to lettuce do not improve yield but do improve phosphorus availability. Acta Agriculturae Scandinavica Plant soil science 55(1):58- 63 https://doi.org/10.1080/09064710510008559

Davison, J (1988). Plant beneficial bacteria. Biotechnology 6:282-286. https://doi.org/10.1038/nbt0388-282

Dolgen D, Alpaslan MN, Delen N (2007). Agricultural recycling of treatment-plant sludge: A case study for a vegetableprocessing factory. Journal of Environment and Management 84:274-281. https://doi.org/10.1016/j.jenvman.2006.06.013

Ejaz M, Waqas R, Butt M, Rehman S, Manan A (2011). Role of macro-nutrients and micro-nutrients in enhancing the quality of tomato. International Journal Agronomy Veterinary Medicine Science 5:401-404. https://doi.org/10.5455/ijavms.20110815111114

Giovanelli G, Paradiso A (2002). Stability of dried and intermediate moisture tomato pulp during storage. Journal of Agricultural and Food Chemistry 50:7277-7281. https://doi.org/10.1021/jf025595r

Hosseinzadeh SR, Ahmadpour R (2018). Evaluation of vermicompost fertilizer application on growth, nutrient uptake and photosynthetic pigments of lentil (Lens culinaris Medik.) under moisture deficiency conditions. Journal of Plant Nutrition 41(10):1276-1284. https://doi.org/10.1080/01904167.2018.1450419

Hosseinzadeh SR, Amiri H, Ismaili A (2016). Effect of vermicompost fertilizer on photosynthetic characteristics of chickpea (Cicer arietinum L.) under drought stress. Photosynthetica 54(1):87-92. https://doi.org/10.1007/s11099-015-0162-X

Hosseinzadeh SR, Amiri H, Ismaili A (2017). Nutrition and biochemical responses of chickpea (Cicer arietinum L.) to vermicompost fertilizer and water deficit stress. Journal of Plant Nutrition 40(16):2259-2268. https://doi.org/10.1080/01904167.2016.1262412

Keles Y, Oncel I (2004). Growth and solute composition on two wheat species experiencing combined influence of stress conditions. Russian Journal of Plant Physiology 51:203-208. https://doi.org/10.1023/B:RUPP.0000019215.20500.6e

Lakhdar A, Rabhi M, Ghnaya T, Montemurro F, Jedidi N, Abdelly C (2009). Effectiveness of compost use in salt-affected soil. Hazardous Materials 171(3):29-37. https://doi.org/10.1016/j.jhazmat.2009.05.132

Lichtenthaler HK (1987). Chlorophylls and carotenoids: pigments of photosynthetic biomembranes. Methods in Enzymology 148:350-382. https://doi.org/10.1016/0076-6879(87)48036-1

Lichtenthaler HK, Welburn AR (1983). Determination of total carotenoids and chlorophylls A and B of leaf extracts in different solvents. Biochemical Society Transactions 11:591-592.

Loggini B, Scartazza A, Brugonli E, Navari-Izzo F (1999). Antioxidative defense system, pigment composition, and photosynthetic efficiency in two wheat cultivars subjected to water. Plant Physiology 119:1091-1099. https://doi.org/10.1104/pp.119.3.1091

Mylavarapu RS, Zinati GM (2009). Improvement of soil properties using compost for optimum parsley production in sandy soils. Scientia Horticulturae 120:426-430. https://doi.org/10.1016/j.scienta.2008.11.038

Rahbarian R, Khavari-nejad R, Ganjeali A, Bagheri AR, Najafi F (2011). Drought stress effects on photosynthesis, chlorophyll fluorescence and water relations in tolerant and susceptible chickpea (Cicer arietinum L.) genotypes. Acta Biologica Cracoviensia-Series Botanica 53:47-56. https://doi.org/10.2478/v10182-011-0007-2

Rasti Sani M, Lahouti M, Ganjeali A (2014). Effect of drought stress on some morphophysiological traits and chlorophyll fluorescence of red bean seedlings (Phaseolus vulgaris L.). Iranian Journal of Pulses Research 5(1):103-116.

Sairam RK, Saxena DC (2001). Oxidative stress and antioxidants in wheat genotypes: possible mechanism of water stress tolerance. Journal of Agronomy and Crop Science 184:55-61. https://doi.org/10.1046/j.1439-037x.2000.00358.x 
Sajadi Nik R, Yadavi A, Balouchi HR and Farajee H (2011). Effect of chemical (Urea), organic (vermicompost) and biological (Nitroxin) fertilizers on quantity and quality yield of sesame (Sesamum indicum L.). Journal of Sustainable Agriculture and Production Science 21:87-101.

Sallaku G, Babaj I, Kaciu S, Balliu A (2009). The influence of vermicompost on plant growth characteristics of cucumber (Cucumis sativus L.) seedlings under saline conditions. Journal of Food, Agriculture and Environment 7:869-872.

Samiran R, Kusum A, Biman KD, Ayanadar A (2010). Effect of organic amendments of soil on growth and productivity of three common crops viz. Zea mays, Phaseolus vulgaris and Abelmoschus esculentus. Applied Soil Ecology 45:78-84. https://doi.org/10.1016/japsoil.2010.02.004

Sanchez-Rodrguez E, Rubio-Wilhelmi M, Cervilla LM, Blasco B, Rios JJ, Rosales MA, Romero L, Ruiz JM (2010). Genotypic differences in some physiological parameters symptomatic for oxidative stress under moderate drought in tomato plants. Plant Science 178:30-40. https://doi.org/10.1016/j.plantsci.2009.10.001

Tan KH (2003). Humic matter in soil and environment: principles and controversies. CRC Press, New York, 408 p. https://doi.org/10.1201/9780203912546

Warman PR, AngLopez MJ (2010). Vermicompost derived from different feedstocks as a plant growth medium. Bioresource Technology 101:4479-4483. https://doi.org/10.1016/j.biortech.2010.01.098

Wilson DP, Carlile WR, Vidal O (1989). Plant growth in potting media containing worm-worked duck waste. Acta Horticulturae 238:205-220. https://doi.org/10.17660/actahortic.1989.238.24

Xie L, Ying Y, Ying T (2007). Combination and comparison of chemometrics method for identification of transgenic tomatoes using visible and near-infrared diffuse transmittance technique. Journal of Food Engineering 82:395-401. https://doi.org/10.1016/j.jfoodeng.2007.02.062

Yanga L, Zhaoa F, Changa Q, Li T, Li F (2015). Effects of vermicomposts on tomato yield and quality and soil fertility in greenhouse under different soil water regimes. Agricultural Water Management 160:98-105. https://doi.org/10.1016/j.agwat.2015.07.002
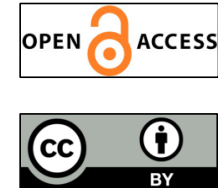

The journal offers free, immediate, and unrestricted access to peer-reviewed research and scholarly work. Users are allowed to read, download, copy, distribute, print, search, or link to the full texts of the articles, or use them for any other lawful purpose, without asking prior permission from the publisher or the author.

License - Articles published in Notulae Botanicae Horti Agrobotanici Cluj-Napoca are Open-Access, distributed under the terms and conditions of the Creative Commons Attribution (CC BY 4.0) License. (c) Articles by the authors; UASVM, Cluj-Napoca, Romania. The journal allows the author(s) to hold the copyright/to retain publishing rights without restriction. 